\title{
Evaluation of the Effectiveness of Simulation and Web Based Training Methods in the Development of Knowledge and Skills of Urinary İncontinence Management in Nursing Students
} Hemşirelik Öğrencilerinin Üriner İnkontinans Yönetimi Bilgi ve Becerilerinin Geliştirilmesinde Simülasyon ve Web Tabanlı Eğitim Yöntemlerinin Etkinliğinin Değerlendirilmesi

(D) Tuba YILMAZER, id Hilal TÜZER

Ankara Yıldırım Beyazıt University, Department of Nursing, Ankara, Turkey

\section{ABSTRACT}

Objective: The aim of this study was to evaluate the effectiveness of simulation and web based training methods in developing knowledge and skills of urinary incontinence (UI) management in nursing students.

Methods: This study was a single blind, randomized controlled study. It was conducted with 75 period 2 nursing students. The research was carried out in 3 stages. In the first stage; all students were given theoretical training about UI management and pretest was applied. Then, students were divided into three groups, each of which consisted of 25 students, by block randomization method (Intervention 1 group, intervention 2 group and control group). In the second stage, intervention 1 group was trained with the simulation training, and intervention 2 group was trained with web-based training. The control group underwent no intervention. The third stage was initiated after 3 months in order to evaluate the effectiveness of knowledge and skills in the long term. All of the students' skills were evaluated on a real patient with UI and posttest was applied.

Results: It was found that the change in knowledge level in intervention 1 and intervention 2 groups was similar ( $\mathrm{p}=0.086$ ), but the level of knowledge in both groups was increased more than

\section{ÖZ}

Amaç: Hemşirelik öğrencilerinin üriner inkontinans (Üİ) yönetimi bilgi ve becerilerinin geliştirilmesinde simülasyon ve web tabanlı eğitim yöntemlerinin etkinliğinin değerlendirilmesi amaçlanmıştır.

Yöntemler: Tek kör, randomize kontrollü olarak yapılan bu çalışma, ikinci sınıftaki toplam 75 hemşirelik öğrencisi ile üç aşamada gerçekleştirilmiştir. Birinci aşamada; öğrencilerin tamamına Üİ yönetimiyle ilgili teorik bilgi verilip ön test uygulanmıştır. Daha sonra ögrenciler blok randomizasyon yöntemiyle; müdahale1, müdahale 2 ve kontrol grubu olmak üzere 25 'er kişiden oluşan üç gruba ayrılmıştır. İkinci aşamada; müdahale 1 grubu simülasyon eğitim yöntemiyle, müdahale 2 grubu web tabanlı eğitim yöntemiyle eğitilmiş, kontrol grubuna ise herhangi bir müdahalede bulunulmamıştır. Üçüncü aşamada eğitimlerden üç ay sonra grupla rarasında bilgi ve becerilerin uzun vadede etkinliğini belirlemek amacıyla öğrencilerin tamamının becerileri Üİ'si olan gerçek hasta üzerinde değerlendirilmiş ve öğrencilere son test uygulanmıştır.

Bulgular: Müdahale 1 ve müdahale 2 gruplarındaki bilgi düzeyi değişiminin benzer düzeyde olduğu $(\mathrm{p}=0,086)$ ancak her iki gruptaki bilgi düzeyinin kontrol grubuna göre daha da arttığı belirlenmiştir

Address for Correspondence: Tuba YILMAZER, Ankara Yıldırım Beyazıt University, Department of Nursing, Ankara, Turkey

E-mail: tyilmazer@ybu.edu.tr ORCID ID: orcid.org/0000-0002-4052-8753

Cite this article as: Yılmazer T, Tüzer H. Evaluation of the Effectiveness of Simulation and Web Based Training Methods in the Development of Knowledge and Skills of Urinary İncontinence Management in Nursing Students. Bezmialem Science 2020;8(2):163-9. 
the control group $(\mathrm{p}<0.001)$. In addition, the skills level was the highest in the intervention 1 group and the lowest in the control group $(\mathrm{p}<0.05)$.

Conclusion: Although simulation and web based trainings have a positive and similar effect on the level of knowledge, it is seen that simulation training has more impact on skill level than web-based training.

Keywords: Simulation training, web based training, urinary incontinence management, nursing students $(p<0,001)$. Ayrıca beceri düzeyinin müdahale 1 grubunda en yüksek, kontrol grubunda en düşük olduğu saptanmıştır $(\mathrm{p}<0,05)$.

Sonuç: Simülasyon ve web tabanlı eğitimin öğrencilerin bilgi düzeyi üzerinde olumlu ve benzer etkisi görülse de; beceri düzeyinde simülasyon eğitimi web tabanlı eğitime göre daha etkilidir.

Anahtar Sözcükler: Simülasyon eğitimi, web tabanlı eğitim, üriner inkontinans yönetimi, hemşirelik öğrencileri

\section{Introduction}

Nursing is a practical health discipline covering the processes for the realization of cognitive, affective and psychomotor learning $(1,2)$. Today, with the development of technology, in addition to traditional training methods, innovative training methods are preferred for students to develop cognitive, affective and psychomotor skills. In nursing education, especially the increasing number of students, the appropriate clinical practice area and the low number of trainers have made it necessary to integrate innovative training methods such as simulation training and web-based training into nursing education (1-3).

Simulation training allows students to learn by gaining experience in many subjects such as providing patient safety and developing evaluation skills for psychiatric nursing; allows students to develop their cognitive, affective and psychomotor skills in these subjects in the short and long term (3-5); and reduces the fear and anxiety of making mistakes and enables students to adequately reflect their knowledge and skills into real patient care even after three to six months (6-8). In a pretest-posttest evaluation study conducted on nursing students to examine the development of basic information in intensive care nursing, it was determined that the persistence of knowledge in students increased significantly 3 months after simulation training (9). In another study to determine the effect of simulation training on nursing students on cognitive skills and confidence level, it was determined that cognitive skills improved significantly after 6 months, but there was no significant difference in confidence levels (10). Web-based training is a cost-effective and useful practice that aims to improve students' cognitive, affective and psychomotor skills (11). Web-based training is considered to be an important training method for eliminating time and limit barriers, providing 24-hour access to information and supporting learning (12). In a study that evaluated the effect of web-based training on hand washing knowledge and skills on nursing students, it was determined that knowledge and skills increased significantly after 8 weeks (13).

Urinary incontinence (UI) is a major and widespread problem worldwide, affecting the psychological, physical, social and economic well-being of individuals and their families $(14,15)$. $\mathrm{UI}$ is reported to be more common in women and about $10 \%$ of all women face this problem. Its prevalence increases as age increases, affecting more than $40 \%$ of women aged 70 years $(14,16)$. The prevalence of UI in women has been reported to vary between $25-45 \%$ (17) in the world and $20-25 \%$ in Turkey
$(18,19)$. It is important to consider and evaluate this problem carefully considering that the rates of UI are quite high and people/families are affected psychologically, physically, socially and economically. UI, which is a preventable problem and is very common, requires the nursing profession to be better equipped in this regard. The acquisition of this equipment requires studies that assess the impact of innovative training methods such as simulation training and web-based training on the persistence of knowledge and skills in the long term. It was thought that this study would make an important contribution to the literature at this point.

\section{Aim and Questions of the Study}

The aim of this study was to evaluate the effectiveness of simulation and web-based training methods in the development of nursing students' knowledge and skills in UI management. The following study questions were created in line with the purpose of the study.

Is there a difference between groups (simulation training, webbased training and control group) in terms of nursing students' knowledge development related to UI management?

Is there a difference between groups (simulation training, webbased training, and control group) in terms of nursing students' skills development related to UI management?

\section{Methods}

\section{Form of the Study}

This study was conducted as a single blind randomized controlled trial.

\section{Universe and Sample of the Study}

The universe of the study consisted of 130 students in the nursing department of a university in Ankara who took the course of "Internal Medicine Nursing" between December 2018 and March 2019. The sample of the study consisted of 75 students who agreed to participate in the study.

\section{Criteria for Inclusion in the Study:}

1. To be enrolled in the course of "Internal Medicine Nursing",

2. Active participation in the course of "Internal Medicine Nursing",

3. Agreeing to participate in the study. 


\section{Criteria for Exclusion from the Study:}

1. Not participating to theoretical education of the course of "Internal Medicine Nursing",

2. Not participating in simulation and video based training,

3. Not participating in clinical practice of the course of "Internal Medicine Nursing",

4. Not working with a patient with UI,

4. Refusing to participate in the study.

\section{Data Collection Forms}

Demographic information including the age and gender of the participants were collected and the "Assessment Form (Form 1) on knowledge level related to UI management" and the "Skills Assessment Form (Form 2) for management of UI" were used. The final versions of these forms prepared by the researchers in accordance with the literature were formed by taking opinions of 5 experts.

\section{Assessment Form (Form 1) on Knowledge Level Related to} Urinary Incontinence management; this form was created by the researcher by scanning the literature to measure the level of knowledge of nursing students on what urinary incontinence meaned, why it occured, risk factors, diagnostic methods, conservative (pelvic floor muscle exercises, bladder training, toilet programs, etc.), medical and surgical treatment methods, and nursing care of UI $(5,14-17)$. The form was prepared on a multiple choice basis and contained a total of 20 questions. The score that was taken from each correctly answered question was 5 and the score range of the form varied between 0 and 100 points.

Skills Assessment Form (Form 2) for Management of Urinary Incontinence; this form was created by the researcher by scanning literature to evaluate nursing students' skills related to urinary incontinence $(6,14-17)$. The form contained a total of 20 items and included options for each item that could be marked as "not observed", "missing/incorrect" and "correct/complete", and these categories were rated 0,1 , and 2 , respectively. The score that could be taken from each "correct/complete" answer was 2 and the score range of the form varied between 0 and 40 points. Performance scores were obtained by converting the sum of the scores in this form to a scale of 0-100.

\section{Application of the Study}

The study was carried out in three stages (Figure 1).

\section{First Stage:}

Theoretical knowledge about management of UI was given by the researchers to all students ( 75 students) during a lecture hour by expression and demonstration method. At the end of the training, a question-answer session was held. Then, pre-test was applied to all the students who participated in the study and the knowledge levels of the students were evaluated. Students were divided into three groups (25 students, intervention 1 group; 25 students, intervention 2 group; 25 students, control group) using the block randomization method. By block randomization method, the first three students were included in group I, II and III, respectively; then the second three in group II, III and I, respectively and then the third three in group III, I and II,

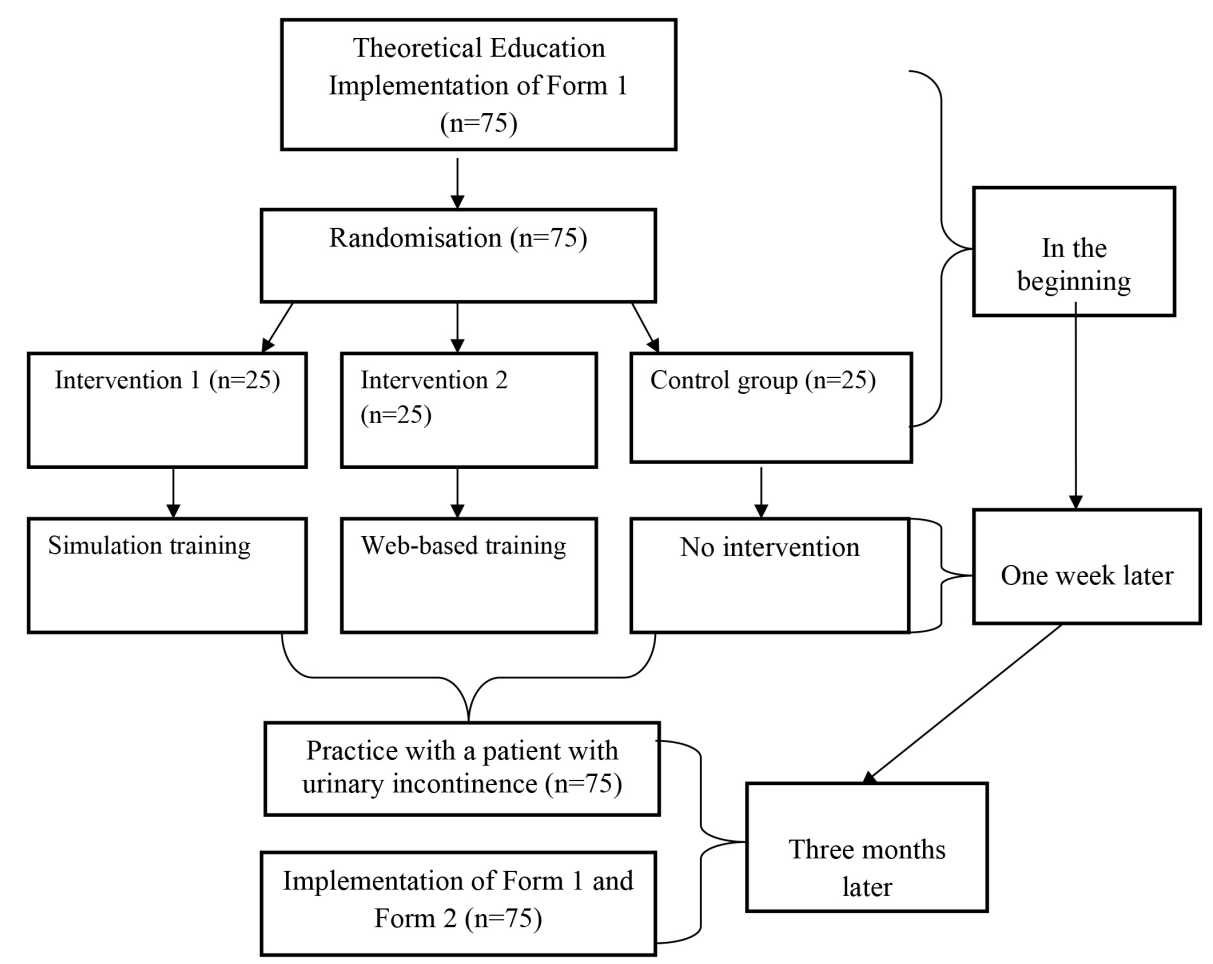

Figure 1. Stages of the study 
respectively. Then, they were distributed to the groups in the same way.

\section{Second Stage:}

1. Intervention 1 group was given a new 20 -minute training about UI management one week later with demonstration method and with standard patient accompaniment. The training given by the researchers was about what urinary incontinence meaned, why it occured, risk factors, diagnostic methods, conservative (pelvic floor muscle exercises, bladder training, toilet programs, etc.), medical and surgical treatment methods, and nursing care of UI. After the training, the students were released to self-study with the standard patient. Student applications were recorded on video during the study. The analysis session was then conducted. During the analysis session, the videotaped applications of the students were monitored by both the student and the researcher. In the meantime, students were given feedback on their practice skills.

2. Intervention 2 group was given web-based training on UI management one week later. The researchers prepared a video about what UI meaned, why it occured, risk factors, diagnostic methods, conservative (pelvic floor muscle exercises, bladder training, toilet programs, etc.), medical and surgical treatment methods, and nursing care of UI. The video was uploaded to the web environment for students to reach and was watched by the students.

3. To q control group was not interfered other than theoretical training.

\section{Third Stage:}

The third stage of the study was carried out three months later. Three months after simulation and web-based theoretical and practical training, each student in the three groups performed a practice on a female patient with UI during the clinical practice. During this application, the students' skill levels were evaluated using the "Skills assessment form on UI management (Form 2)" by the two instructors who were not involved in the study. These two faculty members did not know which group the students were in. The final test was applied to all the students who participated in the study and their knowledge levels were re-evaluated at the end of the third month.

\section{Limitations of the Study}

Considering that UI was more common in women, only female patients were used in the actual patient practice of the study.
It is also recommended that male patients be included in other studies on this subject.

\section{Ethical Aspects of the Study}

The authorization and ethical approval of the study was taken from Ankara Yıldırım Beyazit University (2018/86). The aim of the study was explained to the students and their written consent was obtained. It was stated to the students that whether or not they participated in the study was not part of the education and would never affect the educational process. During the clinical practice, the female patients with UI were informed about the study and their approval was obtained.

\section{Statistical Analysis}

The distribution of information and performance scores in the study was examined with the Shapiro-Wilk test. All scores were expressed in mean \pm standard deviation and median (min-max). Knowledge and performance scores were obtained by converting the sum of the scores in the relevant form to a scale of 0-100. The knowledge and performance scores of the groups were compared with the Kruskal-Wallis test. The Bonferroni-Dunn Correction was applied for binary comparisons. The variation of information scores in groups was compared with the F1-LD-F1 design. As a result of this test, a $\mathrm{p}$ value for Anova-type-statistic was given for intergroup differences and group*test time interaction. A p value $<0.05$ was accepted as statistically significant. For statistical analysis and calculations, IBM SPSS Statistics 21 . 0 program (IBM Corp. Releasedin 2012. IBM SPSS Statistics for Windows, Version21.0. Armonk, NY: IBM Corp.) was used and for graphic drawing, Microsoft Office Excel 2013 was used.

\section{Results}

The average age of 75 students in the study was $20.7 \pm 0.8$ years and the majority $(84 \%)$ were female (Table 1$)$.

The median of the pretest knowledge score was 35 [minimummaximum (min-max): 20-65] in intervention 1 group, 35 (minmax: 15-70) in intervention 2 group and 35 (min-max: 20-65) in control group (Table 2; Figure 2). There was no difference between the groups in terms of pretest knowledge score $(\mathrm{p}=0.911)$. The posttest knowledge score was significantly higher in intervention 1 group and intervention 2 group than in control group $(p<0.05)$. There was no significant difference between the intervention 1 and Intervention 2 groups in terms of the posttest knowledge score $(\mathrm{p}=0.260)$.

When pretest and posttest knowledge scores were examined, it was determined that there was a significant change in intervention 1

Table 1. Characteristics of students ( $n=75)$

\section{Characteristics}

\section{Age (years)}

Average \pm standard deviation
Gender

Female

Male
Intervention 1 group $(n=25)$
Intervention 2 group ( $n=25)$
Control group ( $n=25) \quad$ Total

\begin{tabular}{|l|l|l|l|}
\hline $20.6 \pm 0.6$ & $20.6 \pm 0.8$ & $20.7 \pm 0.8$ & $20.7 \pm 0.8$ \\
\hline $21(84 \%)$ & $22(88 \%)$ & $20(80 \%)$ & $63(84 \%)$ \\
\hline $4(16 \%)$ & $3(12 \%)$ & $5(20 \%)$ & $12(16 \%)$ \\
\hline
\end{tabular}


and intervention 2 groups $(\mathrm{p}<0.001)$ and that knowledge scores remained at a similar level in the control group $(\mathrm{p}=0.423)$. When information score changes were compared, it was found that the change in intervention 1 and intervention 2 groups was similar $(p=0.086)$ but the scores in both groups increased compared to the control group $(\mathrm{p}<0.001)$.

The performance score distributions of the groups are given in Table 2 and Figure 3. Performance score was found to be highest in intervention 1 group and lowest in control group $(\mathrm{p}<0.05)$

\section{Discussion}

It is observed that innovative training methods such as simulation training and web-based training are applied in order to gain sufficient knowledge and skills and to provide cognitive, affective and psychomotor learning in nursing education $(5,11)$. When these training methods are applied separately, it is seen that they provide long-term knowledge and skills persistence for nursing students $(9,10,13)$. When the literature was examined, it was observed that a limited number of studies were conducted on the employees to assess the effectiveness of these training methods on the persistence of knowledge and skills in the long term (20-22). However, it has not been observed that the effects of these training methods on the long-term persistence of knowledge and skills have been determined by evaluating them together. There has also been no study on the management of UI in this area. Based on this point, this study was conducted as a randomized controlled trial to evaluate the effectiveness of simulation and web-based training methods in the development of the knowledge and skills in the management of UI of nursing students.

In a randomized controlled trial, where simulation and webbased training methods were compared on nurses, it was determined that knowledge levels in both methods were similarly increased in the short term and long term (at the end of the second month). The skills of nurses who received simulation training were found to be higher in the short term and in the long term (at the end of the second month) (20). In a study where simulation and web-based trainings about intravenous administration were given to radiography specialists, it was found that both methods increased the level of knowledge, but the increase in simulation training was more without reaching statistical significance. In both groups, it was observed that the persistence of knowledge after six months was ensured (21). In a semi-experimental study comparing simulation and web based training methods on midwives, it was determined that there was a significant improvement in midwives with both methods and no difference was found between groups (22). In a randomized controlled trial, simulation and web based training methods were

Table 2. Comparison of knowledge and skill scores of intervention 1, intervention 2 and control groups

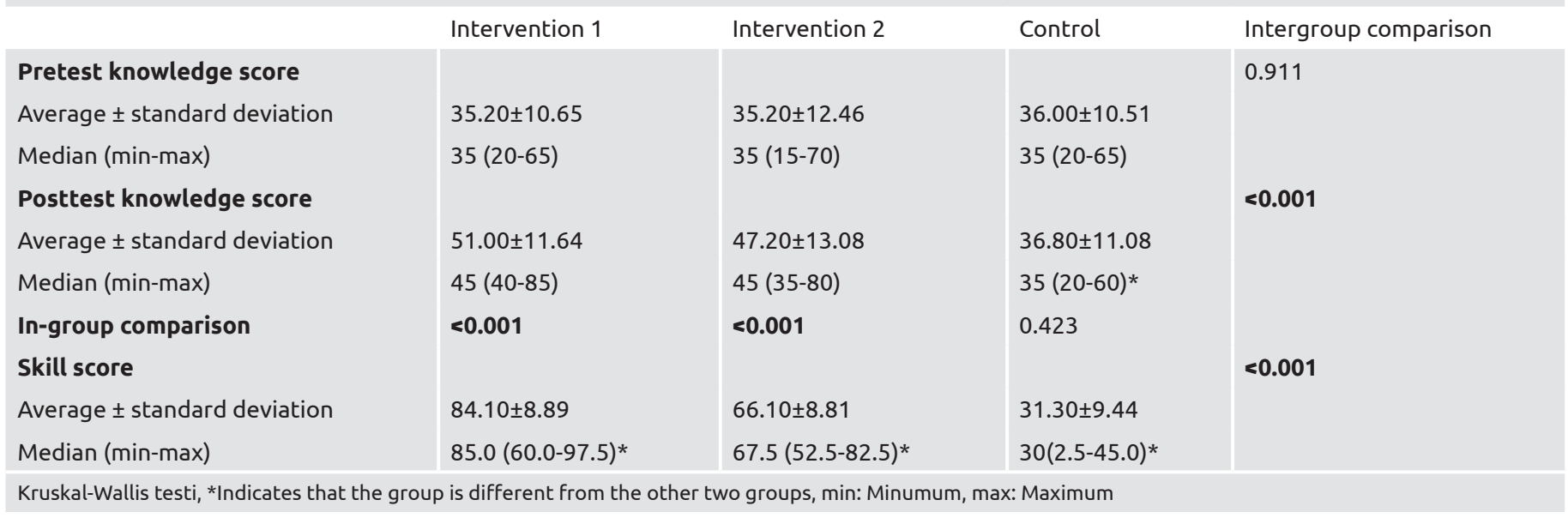

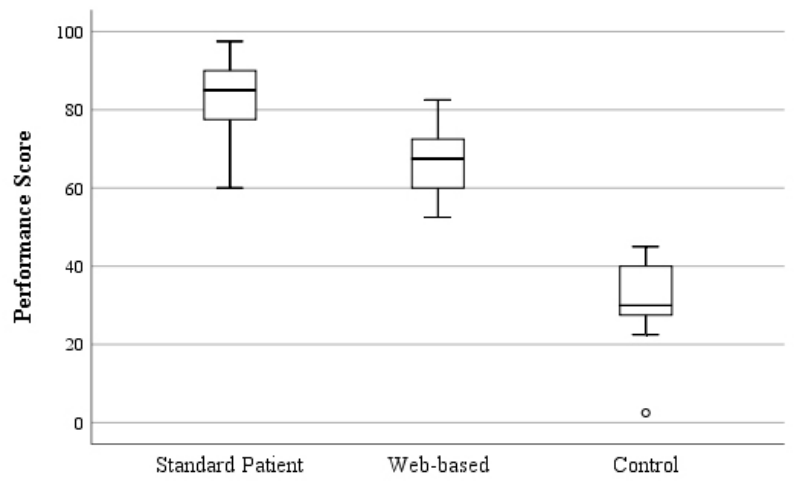

Figure 3. Distribution of skill level of groups

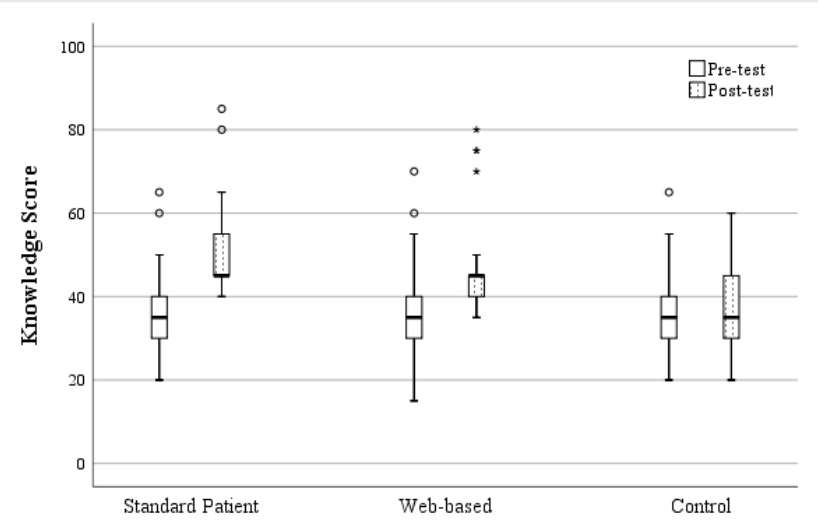

Figure 2. Distribution of knowledge level of groups 
used on midwives for postpartum hemorrhage volume estimation and it was determined that there was a significant improvement in midwives with both methods and no difference was found between groups (23). Similarly, when changes in knowledge level were compared between the groups, it was determined that the change in intervention 1 and intervention 2 groups was similar $(\mathrm{p}=0.086)$ and that the knowledge level in both groups was more increased compared with control group $(\mathrm{p}<0.001)$. In addition, skill levels were found to be highest in intervention 1 group and lowest in control group $(\mathrm{p}<0.05)$. Although simulation and web-based trainings had a positive and similar effect on knowledge level, simulation training had more impact on skill level than web-based training. This was thought to be related to providing students with a realistic learning environment where they experienced real-life situations through simulation training (24-26). It was also thought that the analysis session affected this result. It is known that effective learning is achieved through feedback during the analysis session and positive aspects of skill are reinforced. This enables the student to relate theoretical knowledge with practice and enables the performance permanent $(27,28)$.

\section{Conclusion}

Although both innovative training methods such as simulation training and web-based training had a positive and similar effect on knowledge level, simulation training had more impact on skill level than web-based training. Further research is needed assessing the effectiveness of simulation and web-based training methods on gaining knowledge and skills in the management of urinary incontinence in nursing students.

\section{Ethics}

Ethics Committee Approval: The authorization and ethical approval of the study was taken from Ankara Yıldırım Beyazit University (2018/86).

Informed Consent: Obtained.

Peer-review: Externally peer reviewed.

\section{Authorship Contributions}

Concept: T.Y., H.T., Design: T.Y., H.T., Data Collection or Processing: T.Y., H.T., Analysis or Interpretation: T.Y., H.T., Literature Search: T.Y., Writing: T.Y., H.T.

Conflict of Interest: No conflict of interest was declared by the authors.

Financial Disclosure: The authors declared that this study received no financial support.

\section{References}

1. Cooper S, Endacott, R, Cant R. Measuring nontechnical skills in medical emergency care: A review of assessment measures. Emergency Medicine 2010;2:7-16.

2. Gillespie BM, Polit DF, Hamlin L, Chaboyer W. Developing a model of competence in the OR: Psycometric validation of perceived perioperative competence scale-revised. International Journal Nursing Studies 2012;49:90-101.

3. Robinson-Smith G, Bradley PK, Meakim C.Evaluating the use of standardized patients in undergraduate psychiatric nursing experiences November. Clinical Simulation in Nursing 2009;5(6):e203-e211. doi:10.1016/j.ecns.2009.07.001.

4. Robertson B, Kaplan B, Atallah H, Higgins M, Lewitt MJ, Ander DS. The use of simulation and a modified team STEPPS curriculum for medical and Nursing student team training. The Journal of the Society for Simulation in Healthcare 2010;5:332-7.

5. Crowe S, Ewar L, Derman S. Theimpact of simulation based education on nursing confidence, knowledge and patient outcomes on general medicine units. Nurse Education in Practice 2018;29:705 .

6. Houghton CE, Casey D, Shaw D, Murphy K. Students' experiences of implementing clinical skills in the real word of practice. Journal of Clinical Nursing 2013;22:1961-9.

7. McNett S. Teaching nursing psychomotor skills in a fundamentals laboratory: A literature review. Nurse Education Perspectives 2012;33:328-33.

8. Ross JG. Simulation and psychomotor skill acquisition: A review of the literature. Clinical Simulation in Nursing 2012;8:e429-e435.

9. Hoffmann R, O'Donnell J, Kim Y. The effects of human patient simulators on basic knowledge in critical care nursing with undergraduate senior baccalaureate nursing students. Simulation in Healthcare 2007;2:110-4.

10. Brannan J, White A, Bezanson J. Simulator effects on cognitive skills and confidence levels Journal of Nursing Education 2008;47:495500.

11. Hadjiconstantinou M, Byrne J, Bodicoat D H, Robertson N, Eborall H, Khunti K, Davies M. J. Do web-based interventions improve well-being in type 2 diabetes? A systematic review and meta-analysis. Journal of Medical Internet Research 2016;18:270.

12. Elgaphar SMA, El Gafar SIA. Effect of tele-nursing (phonebasedfollow-ups) on self efficacy healthy lifestyle and glycemic control in diabetic patients IOSR Journal of Nursing and Health Science (IOSR-JNHS) 2017;6:67-76.

13. Bloomfield J, Roberts J, While A. The effects of computer assisted learning versus conventional methods on the acquisition and retention of handwashing theory and skills in pre-qualification nursing students: a randomized controlled trial. International Journal of Nursing Studies 2010;47:287-94.

14. Milsom I, Gyhagen M. The prevalence of urinary incontinence, Climacteric 2018;1-6. DOI: 10.1080/13697137.2018.1543263

15. Wagner T, Moore K, Subak L, De Wachter S, Dudding T. Economics of urinary and faecal incontinence, and prolapse. In:Abrams $\mathrm{P}$, Cardozo L, Wagg A, Wein A, eds. Incontinence. 6th ed. Paris: Health Publications Ltd; 2016:17-24

16. Irwin DE, Kopp ZS, Agatep B, Milsom I, Abrams P. Worldwide prevalence estimates of lower urinary tract symptoms, overactive bladder, urinary incontinence and bladder outlet obstruction. BJU Int 2011;108:1132-8. 
17. Milsom I, Altman D, Cartwright R, et al. Epidemiology of urinary incontinence (UI) and other lower urinary tract symptoms (LUTS), pelvic organ prolapse (POP) and anal (AI) incontinence. In: Abrams P, Cardozo L, Wagg A, Wein A, eds. Incontinence. 6th ed. Paris: Health Publications Ltd; 2016:17-24

18. Maral I, Özkardeş H, Peskircioğlu L,Bumin MA. Prevalence of stres urinary incontinence in both sexes at or after age 15 years: a crosssectional study. J Urol 2001;165:408-12

19. Özerdoğan N, Beji NK, Yalçın O. Urinary incontinence: its prevalance, risk factors and effects on the quality of life of women living in a region of Turkey. Gynecol Obstet Invest 2004;58:145-50

20. Rutherford-Hemming T, Kelsey NC, Grenig DL, Feliciano M, Simko L, Henrich CM. Multisite single-blinded randomized control study of transfer and retention of knowledge and skill between nurses using simulation and online self-study module. Simulation in Healthcare 2016;11:264-70.

21. Aura SM, Paakkonen HJ, Metsavainio K, Saano SSM, Selander TA, Jordan SE, TurunenHE. Simulation- and web-based learning of intravenous pharmacotherapy: A 2-group comparison with 6 months' follow-up. Journal of Radiology Nursing 2017;36:117-24.

22. Fakari FR, Kordi M, Mazloom SR, Khadivzadeh T, Tara M, Akhlaghi F. Comparing the effect of traditional, web based and simulation training on midwifery students' clinical competence in postpartum hemorrhage management. J Mazandaran Univ Med Sci 2015;25:6577.

23. Kordi M, Fakari FR, Mazloom SR, Khadivzadeh T, Akhlaghi F, Tara M. Comparison of the effect of web-based, simulation-based, and conventional training on the accuracy of visual estimation of postpartum hemorrhage volume on midwifery students: A randomized clinical trial. J EducHealthPromot 2016;5:22.

24. Harrington KL, Palley JE, Pfeiffer CE. Impact of thesite specialty of a continuity practice on students' clinical skills: Performance with standardized patients. Teaching and Learning in Medicine 2010;22:191-5.

25. Kim JK. Standardized patient identification and specimen labeling: A retrospective analysis on improving patient safety. Journal of the American Academy of Dermatology 2012;68:53-6.

26. Lucktar-Flude M, Wilson B, Larocque M. Evaluating high fidelity human simulators and standardized patients in an undergraduate nursing health assessment course. Nurse Education Today 2012;32:448-52.

27. Jeffries PR. Simulation in nursing education: From Conceptualization to Evaluation. New York, NY: National League for Nursing. 2007.

28. Jeffries PR. A framework for Designing, Implementing, and Evaluating. Nursing Education, Perspectives 2005;26:96-103. 